\title{
Educational Objectives in E-Learning
}

\author{
Stanislava Stoyanova ${ }^{1}$, Lambri Yovkov ${ }^{2}$ \\ ${ }^{1}$ South-West University "Neofit Rilski”, 66, Ivan Mihailov Street, 2700 Blagoevgrad, Bulgaria \\ ${ }^{2}$ Plovdiv University "Paisii Hilendarski”, 236, bul. Bulgaria, 4003 Plovdiv, Bulgaria
}

\begin{abstract}
The educational objectives of e-learning are discussed in this paper. They are based on the taxonomies of cognitive objectives of learning proposed by Bloom, Engelhart, Furst, Hill \& Krathwogl (1956), and Krathwogl (2002), as well as on the taxonomy of both cognitive and affective educational objectives created by Fink (2003). The educational objectives of e-learning are also affective and psychomotor, as suggested by the joined taxonomies of affective objectives of learning presented by Darling (1965), Munzenmaier \& Rubin (2013) and O'Neill \& Murphy (2010), and by the psychomotor objectives of learning described by Draper (2016), Harrow (1972), Munzenmaier \& Rubin (2013), O'Neill \& Murphy (2010), Simpson (1966), and Thomas (2004).
\end{abstract}

Keywords: cognitive objectives of learning, affective objectives of learning, e-learning, psychomotor educational objectives

\section{INTRODUCTION}

During the whole human history people have searched for different ways and methods for improving effectiveness of education and shortening its deadlines. E-learning represents such a way. In recent decades, rapid development of engineering and technology has led to the emergence of entirely new classes of electronic devices. Their capabilities are continuously growing, and their prices fell sharply. As a consequence, they are widespread and they have been gradually included in the learning process. The use of electronic devices in education has led to some changes of the training methods, to completely new and unprecedented pedagogical and didactic methods and tools.

The provider of e-learning can simultaneously train large numbers of students because there is no limit of time and place. E-learning offers high scalability of services - they are easily to be expanded and upgraded ("Merriam-Webster", n.d.), because training of new students does not require more place, neither buying new and expensive electronic devices - the students simply have to use their own devices. Through e-learning providers could deliver more cheaply educational content to their customers because they don't need to travel long distance to schools' or universities' buildings, thus customers save their time and money.

E-learning permits delivering content with no limit to attendance in the form of Massive Open Online Courses ("Educause library", 2016) that expresses the learning objective everyone to be educated. Elearning gives the possibility for easy accessibility to education, even to free quality education.

\section{Cognitive Educational ObJectives of E-Learning}

E-learning has the same objectives of traditional learning. The most popular taxonomy of cognitive educational objectives in face-to-face learning could be applied in e-learning, too. This taxonomy includes as educational objectives the sequence Knowledge - Comprehension - Application Analysis - Synthesis - Evaluation (Bloom, Engelhart, Furst, Hill \& Krathwogl, 1956, pp. 201-207).

Knowledge means learning of specific facts, terms, practices, trends, categories, criteria, principles, theories, etc. (Bloom, Engelhart, Furst, Hill \& Krathwogl, 1956, pp. 201-204). Knowledge could be factual - of terms and elements; conceptual - of categories, principles, theories, models, structures, etc.; procedural - of methods, techniques, algorithms, etc.; and metacognitive knowledge, including self-knowledge, knowledge about contexts and conditions (Krathwogl, 2002, p.214). One of the goals of e-learning is giving and receiving knowledge, remembering things. This goal is realized mainly by reading texts, e-books, watching educational videos and multimedia presentations, listening sound files, doing interactive exercises using Internet connection and other modern equipment and applications such as personal computers, smartphones, tablets, and other devices. 
Remembering, recognizing, and recalling include retrieving relevant knowledge from memory (Krathwogl, 2002, p.215). E-learning permits practicing both recalling (retrieval of information by means of responses formulated by the learners) and recognition (choosing the correct answer among several options). Online testing stimulates self-assessment, self-education and self-knowledge, because of the given feedback.

Comprehension includes interpretation of explanations and summaries, translation in communication, as well as extrapolation, i.e. finding the consequences of some trends (Bloom, Engelhart, Furst, Hill \& Krathwogl, 1956, pp. 204-205). Understanding as a cognitive process is based on interpreting, exemplifying, classifying, summarizing, inferring, comparing and explaining (Krathwogl, 2002, pp. 214-215). Understanding is achieved by means of honing skills based on the received knowledge, trying to find connections between theory and practice in different situations and contexts.

Application includes the use of ideas, theories, procedures, methods and equipment in concrete situations (Bloom, Engelhart, Furst, Hill \& Krathwogl, 1956, p. 205). Applying is based on following, executing, implementing a procedure in a given situation (Krathwogl, 2002, p. 215). Applying knowledge and skills in online education is facilitated by means of mobile applications, webapplications and technical developments.

Analyzing requires separation of a whole into several parts - elements, relationships, and organizational principles (Bloom, Engelhart, Furst, Hill \& Krathwogl, 1956, pp. 205-206). Differentiation of parts, organizing their structure and relationships, and attributing some properties to each part are performed in analyzing (Krathwogl, 2002, pp. 214-215). Analyzing is performed in data collection of information (social-demographic, factual, etc.) from the participants in online education, data storage, data processing, and data distribution of the products and results from e-learning.

Synthesis includes unifying the parts of a whole by means of planning and innovation, informing about findings and scientific achievements.

Evaluation includes estimation of values, methods materials, based on internal criteria such as accuracy, consistency, and external criteria, such as recognized standards (Bloom, Engelhart, Furst, Hill \& Krathwogl, 1956, p. 207). Evaluation in e-learning aims at defining quality and fitness by means of such instruments as tests in most cases.

Krathwogl (2002, p. 214) has changed the places of synthesis and evaluation in the original taxonomy and he has re-named synthesis "create". Putting the parts together to compose a whole entity by means of planning, generating/inventing and producing transforms synthesis into creation preceded by checking for elements and criticizing that both constitute evaluation (Krathwogl, 2002, pp. 214-215).

Another taxonomy of both cognitive and affective learning objectives consists of acquiring fundamental knowledge by means of remembering and understanding information and ideas; its application by means of practical thinking and skills; integration of ideas, areas of life, relations; human dimension related to learning about oneself and the other people; caring by means of feelings, interests and values; and finally learning how to learn (Fink, 2003). Learning how to learn is related to self-education. E-learning encourages learning how to learn, because online learning permits the learner to decide which content to be focused on in a given period, as well as about the timeline of learning process, the number of repetitions of exercises necessary for mastering knowledge and applying skills, how to express one's attitude towards learning, other students and teachers.

\section{AFFECTIVE EduCATIONAL ObJECTIVES OF E-LEARNing}

Learners' emotions are an inherent part of the learning process whose significance is expressed in the taxonomies of affective learning objectives that include interests, attitudes, and values, or receiving, responding, valuing, organizing, and characterization (Darling, 1965; Munzenmaier \& Rubin, 2013; O'Neill \& Murphy, 2010). Visual multimedia demonstrations may contribute to increase in the learner's interest and motivation. E-learning is performed with willingness to be received information, and readiness to be performed the tasks, because this form of learning permits choosing the topic, the preferred time and place for the learners that supposes their positive attitudes to e-learning. The satisfaction from the implemented tasks and received feedback in e-learning contributes to further organization of time and efforts put by the learner, and to characterization using such attributes that correspond to one's values. 
Learners' behaviour corresponds to their values - such as moral integrity, responsiveness, politeness towards the other participant in the educational process, self-control, and other values (Rokeach, 1973). Moral integrity means that learner has created the materials that are assessed, and has properly quoted all the used sources. Self-control and responsiveness are related to timely performing of required tasks. E-learning delivers to users possibilities about self-passed educational courses, thus ensuring opportunity to manage their time and to pass educational courses in comfortable place and with comfortable speed.

The learners can repeat the exercises and simulations over and over again till mastering of new knowledge and skills, without additional financial expenses. Practice is an important part of the learning process, because it contributes to durability of knowledge, skills and habits.

\section{Psychomotor Educational ObJectives of E-Learning}

The psychomotor taxonomies of learning objectives include observation, perceptual abilities and precision; disposition to act, organization for action; reflexes, imitation and guided response; motor activity, fundamental movements, manipulation, habitual responses, simulation; manifested physical abilities and activities, complex responses, synchronisation of multiple activities conforming to the requirements; skilled moves, production, and adaptation; communication, mastery, originality and creative art (Draper, 2016; Harrow, 1972; Munzenmaier \& Rubin, 2013; O’Neill \& Murphy, 2010; Simpson, 1966; Thomas, 2004). Doing online exercises supposes perceptual activity, imitation of some models, manipulation of external devices, and skilled movements related to expression of one's capabilities and communicative intentions in texting, chatting and networking in order to adapt to the environment and the requirements.

The learners communicate and consult the teachers and the other learners by means of email, chat, wikis, etc. The learners receive individual feedback for their results by their teachers and peers. Elearning permits individual approach not only in personal feedback, but because the learners could put their efforts and take time off to study the chosen topic, depending on their individual interests and needs. Multimedia and multisensory materials used in e-learning facilitate the learners to use their preferred learning style - auditory, visual or kinaesthetic.

\section{Conclusion}

E-learning objectives correspond to traditional learning objectives, as well as to life-long learning objectives related to cognitive, affective and psychomotor domains.

The continuous and rapid change of contemporary society and existing technologies leads to life-long education. E-learning is a part of life-long learning that may become more popular. Some corporations (for example BMW Group Canada, according to "IOMA", 2006; Boeing, according to "Business Wire", 2009; IBM, according to "IBM", n. d.) use e-learning to train their employees without any need for leaving their workplace and also improve their skills to keep pace with constantly changing requirements of the highly competitive business environment.

\section{REFERENCES}

Bloom, B. S., Engelhart, M. D., Furst, E. D., Hill, W. H., \& Krathwogl, D. R. (Eds.) (1956). Taxonomy of educational objectives: The Classification of Educational Goals. Handbook 1: Cognitive Domain. Ann Arbor, Michigan: Longmans.

Business Wire. (2009). Boeing Selects Boost eLearning To Improve Employee Productivity While Using Google Search. Retrieved in August 2016, from http://www.businesswire.com/news/ home/20090407005335/en/Boeing-Selects-Boost-eLearning-Improve-Employee-Productivity

Krathwogl, D. R. (2002). A revision of Bloom's taxonomy: An overview. Theory into practice, 41(4), 212-218.

Darling, D. W. (1965). Why a taxonomy of affective learning? Educational leadership, 22, 473-522.

Draper, S. (2016). Taxonomies of learning aims and objectives: Bloom, neoBloom, and criticisms. Retrieved in August 2016, from http://www.psy.gla.ac.uk/ steve/best/bloom.html

Educause library. (2016). Massive Open Online Course (MOOC). Retrieved in August 2016, from https://library.educause.edu/topics/teaching-and-learning/massive-open-online-course-mooc

Fink, L. D. (2003). A Self-Directed Guide to Designing Courses for Significant Learning. San Francisco: Jossey-Bass. 
Harrow, A. J. (1972). A Taxonomy of the Psychomotor Domain: A Guide for Developing Behavorial Objectives. New York: David McKay Co.

IBM. (n.d.). Training and development. Retrieved in August 2016, from http://www03.ibm.com/employment/greaterchina/training.html

IOMA. (2006). Cost reduction and control best practices: The best ways for a financial manager to save money (2nd edition). Hoboken, NJ: John Wiley \& Sons.

Merriam-Webster. (n.d.). Scalable. Retrieved in August 2016, from http://www.merriamwebster.com/dictionary/scalable

Munzenmaier, C., \& Rubin, N. (2013). Bloom's taxonomy: What's old is new again. The eLearning Guild. Retrieved in August 2016, from http://educationalelearningresources.yolasite.com/ resources/guildresearch_blooms2013\%20(1).pdf

O’Neill, G. \& Murphy, F. (2010). Assessment guide to taxonomies of learning. Dublin: UCD teaching and learning resources.

Rokeach, M. (1973). The Nature of Human Values. New York: Free Press.

Simpson, J. S. (1966). The classification of educational objectives, psychomotor domain. Office of Education Project No. 5-85-104. Urbana, IL: University of Illinois.

Thomas, K. (2004). Learning taxonomies in the cognitive, affective, and psychomotor domains. White paper. Version 2.1. Rocky Mountain Alchemy. Retrieved in August 2016, from http://www.rockymountainalchemy.com/whitePapers/rma-wp-learning-taxonomies.pdf

\section{AUTHORS' BIOGRAPHY}

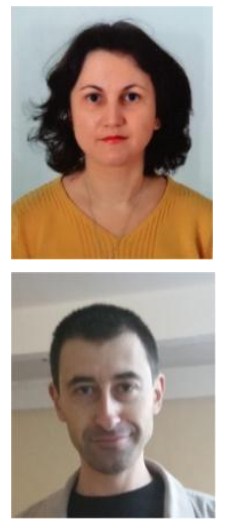

Prof. Stanislava Stoyanova, $\mathrm{PhD}$, works at Department of Psychology at South-West University "Neofit Rilski", Blagoevgrad, Bulgaria. She is a lecturer in Psychological Measurements, Experimental Psychology, and Social Psychology. Her research interests are related to psychology and education.

Lambri Yovkov, is a $\mathrm{PhD}$ student in Pedagogy of E-learning at Faculty of Mathematics and Informatics at Plovdiv University "Paisii Hilendarski" in Plovdiv, Bulgaria. Lambri Yovkov has a Master's degree in Mathematics, and a Master's degree in Informatics. He has worked as a teacher of Computer Science \& Information Technology for several years. 